\title{
ANALISIS MODEL REGRESI SEDIMEN KOLAM LELE, SUKROSA, DAN BIOFERTILIZER TERHADAP PROSES NITRIFIKASI
}

\section{REGRESSION MODEL FOR SEDIMENT FOR SEDIMENTS OF CATFISH PONDS, SUCROSES, AND BIOFERTILIZERS ON THE NITRIFICATION PROCESS}

\author{
Neng Rian Nur'aeni' ${ }^{1)}$, Hanies Ambarsari' ${ }^{2)}$, Rohmatussolihat $^{3)}$, Endang Sukara1)* \\ ${ }^{1)}$ Fakultas Ilmu Hayati, Universitas Surya, Great Western Resort Km.2,7 Lt.1 \\ J1 MH. Thamrin Serpong, Panunggangan Utara, Pinang, Kota Tangerang, Banten 15163 \\ Email: nuraenirian@gmail.com \\ ${ }^{2)}$ Laboratorium Pusat Teknologi Lingkungan (PTL) -BPPT, Puspiptek Serpong, Tangerang Selatan, Banten \\ ${ }^{3)}$ Pusat Penelitian Bioteknologi-LIPI Cibinong Science Center, Cibinong-Bogor, Jawa Barat \\ Makalah: Diterima 14 Agustus 2018; Diperbaiki 12 Maret 2019; Disetujui 26 Maret 2019
}

\begin{abstract}
Response Surface Methodology (RSM) was used to create regression model for sediment of catfish ponds, sucroses, and biofertilizers on the nitrification process. The sediment of catfish pond used was sediment collected from catfish farm at age of 21 days after seed stocking. The nitrification process was done in active sludge reactor of $1 \mathrm{~L}$ reactor working capacity which was entirely given ammonia in the form of $\mathrm{NH}_{3}-\mathrm{N}$ as much as 77.65 ppm. Central Composite Design (CCD) was used to determine the amount of sediment, sucrose, and biofertilizer. The ammonia nitrification process was carried out over a period of 21 days. The three main parameters, including rate of ammonia oxidation $\left(\mathrm{NH}_{3}-\mathrm{N}\right)$, nitrite accumulation $\left(\mathrm{NO}_{2}-\mathrm{N}\right)$, and nitrate accumulation $\left(\mathrm{NO}_{3}-\mathrm{N}\right)$. From this research, it was known that $74 \mathrm{~g} / \mathrm{L}$ sediments of catfish ponds, $6.6 \mathrm{~g} / \mathrm{L}$ sucrose $7.5 \mathrm{~mL} / \mathrm{L}$ biofertilizer were required to obtain maximum ammonia oxidation rate. The result of the verification experiment obtained was $99.85 \%$. In this research, two isolates of bacteria were isolated. Biochemical test using kit of VITEK GN+ (bioMerieux) indicated that the isolated bacteria were belong to the species of Sphingobacterium thalpophilum (probability =99\%) and Cupriavidus pauculus (probabililty = 98\%).
\end{abstract}

Keywords: ammonia, central composite design (CCD), nitrifying bacteria, Response Surface Methodology (RSM)

\section{ABSTRAK}

Penelitian ini bertujuan untuk membuat model regresi pengaruh sedimen kolam, sukrosa dan biofertilizer pada proses nitrifikasi. Analisis model dilakukan dengan menggunakan metode Response Surface Methodology (RSM). Sedimen kolam lele yang digunakan adalah sedimen yang diambil dari kolam lele pada usia 21 hari setelah tebar benih. Proses nitrifikasi dilakukan reaktor sistem lumpur aktif kapasitas kerja reaktor 1 L yang seluruhnya diberi ammonia dalam bentuk $\mathrm{NH}_{3}-\mathrm{N}$ sebanyak 77,65 ppm. Central Composite Design (CCD) digunakan untuk menentukan jumlah sedimen, sukrosa dan biofertilizer yang optimum untuk menghasilkan respon yang tinggi. Proses nitrifikasi amonia dilakukan selama kurun waktu 21 hari. Tiga parameter utama yang diamati yaitul aju penurunan amonia, akumulasi nitrit, dan akumulasi nitrat. Dari penelitian ini diketahui bahwa $74 \mathrm{~g} / \mathrm{L}$ sedimen kolam lele, 6,6 g/L sukrosa7,5 mL/L biofertilizer diperlukan untuk mendapatkan laju penurunan amonia maksimum. Hasil verifikasi eksperimen diperoleh penurunan amonia mencapai 99,85\%. Dalam penelitian ini berhasil diisolasi dua jenis mikroba. Uji biokimia menggunakan kit VITEK GN+ (bioMerieux) diperoleh indikasi bahwa kedua jenis mikroba itu Sphingobacterium thalpophilum (probabilitas $=99 \%$ ) dan Cupriavidus pauculus (probalilitas $=98 \%$ ).

Kata kunci: amonia, bakteri nitrifikasi, Central Composite Design (CCD), Response Surface Methodology (RSM)

\section{PENDAHULUAN}

Limbah cair yang mengandung polutan organik dapat menjadi penyebab terjadinya akumulasi amonia. Amonia umumnya berasal dari proses dekomposisi bahan organik, terutama protein (Effendi et al., 2015). Akumulasi kadar amonia tinggi dapat dijumpai dalam limbah industri karet (Nainggolan et al., 2015), industri tempe (Harahap, 2013), dan kolam ikan seperti lele (Effendi et al., 2015). Potensi amonia yang terakumulasi pada tambak sebesar $75 \%$ dari kadar nitrogen dalam pakan (Gunadi dan Hafsaridewi, 2008). Amonia dapat membunuh organisme perairan khususnya ikan pada konsentrasi 0,06 ppm (Ogbonna dan Chinomso, 2010). Selain itu, pada manusia kadar amonia yang tinggi dapat menyebabkan masalah kesehatan termasuk iritasi mata, kulit, selaput lendir, rongga mulut, dan saluran pernafasan (National Research Council, 2008). Pencemaran amonia juga mengakibatkan kesuburan tanah berkurang (Good dan Beatty, 2011). 
Peraturan Menteri Lingkungan Hidup Republik Indonesia Nomor 5 (2014) menyatakan bahwa kadar amonia bagi usaha atau kegiatan yang belum memiliki baku mutu yang ditetapkan adalah kurang dari 5 ppm. Salah satu metode penanggulangan pencemaran amonia adalah menggunakan sistem lumpur aktif yang didalamnya mengandung mikroba pengurai amonia (Hastuti, 2011).

Central Composite Desaign (CCD) merupakan model regresi dari metode analisa Response Surface Methodology (RSM). Metode RSM memiliki kemampuan untuk menghilangkan kesalahan secara sistematis dengan perkiraan perlakuan ekperimen, meminimalkan jumlah eksperimen, dan menentukan model empiris berdasarkan kecocokan data ekperimen dan design ekeperimen. Kondisi dan pengoptimalan ekperimen yang dilakukan akan ditampilkan dalam sistem fungsi polinomial linear atau kuadratik (Bezzera et al., 2008; Mousavi dan Ibrahim, 2015). Model regresi ditentukan oleh nilai determinasi dan uji-F. Selain itu, uji kelayakan model regresi dapat menghasilkan model prediksi yang layak untuk percobaan (Nuryanti dan Salimy, 2008; El-Gendy et al., 2013).

Penelitian ini difokuskan untuk membuat model regresi proses nitrifikasi (pengurai amonia) dan mengisolasi bakteri yang tahan terhadap amonia tinggi. Untuk itu, limbah cair yang mengandung amonia tinggi dibuat sengaja dengan cara menambahkan amonia dalam bentuk $\mathrm{NH}_{3}-\mathrm{N}$ sebanyak 77,65 ppm kedalam seluruh perlakuan. Pengaruh penambahan sedimen kolam lele, sukrosa, dan biofertilizer dalam lima tingkat kombinasi diteliti dengan menggunakan rancangan Central Composite Design (CCD) dan data yang diperoleh dianalisis dengan menggunakan Response Surfasce Metode (RSM). Laju penguraian amonia, akumulasi nitrit dan nitrat diamati, demikian juga perubahan $\mathrm{pH}$, suhu, dan oksigen terlarut. Pada akhir penelitian, bakteri yang bertanggungjawab dalam proses nitrifikasi diisolasi dan diidentifikasi.

\section{METODE PENELITIAN}

\section{Waktu dan Tempat}

Penelitian ini dilaksanakan dari bulan Oktober 2017 sampai Mei 2018 bertempat di Laboratorium Pusat Teknologi Lingkungan - BPPT,
Gedung 802 Geostech, Puspiptek, Serpong, Tangerang Selatan, Banten 15314.

\section{Penyiapan Reaktor}

Reaktor yang digunakan adalah reaktor sederhana yang dibuat dari galon plastik volume $2 \mathrm{~L}$ dan diberi aerasi dengan laju aliran udara 1500 L/jam.

\section{Penyiapan Sedimen, Sukrosa, dan Biofertilizer}

Sedimen kolam lele diambil dari pembudidaya ikan lele di daerah Pengasinan, Gunung Sindur, Bogor. Sampel sedimen diambil dari empat titik kolam. Sedimen yang digunakan adalah sedimen berumur 21 hari setelah tebar benih sehingga diharapkan mengandung bakteri pengoksidasi amonia yang tahan dalam kadar amonia tinggi. Sukrosa berasal dari Laboratorium BTPAL yang berfungsi sebagai sumber karbon. Sementara itu, Biofertilizer yang digunakan adalah probiotik dengan merk dagang Petrofish yang mengandung bakteri Nitrosomonas europaea, Bacillus subtilis, Bacillus apiarius, dan Lactobacillus plantarum.

\section{Desain dan Prosedur Penelitian}

Desain penelitian yang dipilih adalah Central Composite Design (CCD) menggunakan tiga faktor (sedimen kolam lele, sukrosa, dan biofertilizer) dalam lima level kombinasi (Tabel 1). Penelitian ini menggunakan 20 kombinasi (Tabel 2). Penelitian dilakukan dalam bioreaktor. Seluruh perlakuan diberi amonia $\left(\mathrm{NH}_{3}-\mathrm{N}\right)$ sebanyak 77,65 ppm dan ditera dengan $1 \mathrm{~L}$ akuades. Proses nitrifikasi dilakukan selama 21 hari. Hasil yang diperoleh dianalisis menggunakan metode statistik Response Surface Method (RSM) sehingga diperoleh model regresi laju proses nitrifikasi. Verifikasi dilakukan pada kondisi optimum untuk mengetahui hasil sebenarnya.

\section{Pengujian Parameter}

Tiga parameter, yaitu laju penurunan amonia, laju akumulasi nitrit dan nitrat diukur dan dianalisa menggunakan spektofotometer UV-VIS (berdasarkan metode standar pengujian kadar amonia (secara fenat), nitrit, dan nitrat dari BBPT). Selain itu, perubahan oksigen terlarut, suhu, dan $\mathrm{pH}$ juga diamati menggunakan DO meter dan $\mathrm{pH}$ meter. Parameter diukur dan diamati setiap tiga hari.

Tabel 1. Desain penelitian CCD-RSM

\begin{tabular}{clccccc}
\hline Kode & \multirow{2}{*}{ Faktor } & \multicolumn{5}{c}{ Kode Level } \\
\cline { 3 - 7 } Faktor & & $\mathbf{- \alpha ( - 1 , 6 8 2 )}$ & $\mathbf{- 1}$ & $\mathbf{0}$ & $\mathbf{+ 1}$ & $+\boldsymbol{\alpha}(\mathbf{1 , 6 8 2})$ \\
\hline $\mathrm{X}_{1}$ & Sedimen $(\mathrm{g} / \mathrm{L})$ & 0 & 20 & 50 & 80 & 100,45 \\
$\mathrm{X}_{2}$ & Sukrosa $(\mathrm{g} / \mathrm{L})$ & 0 & 0,7 & 3,7 & 6,7 & 8,75 \\
$\mathrm{X}_{3}$ & Biofertilizer $(\mathrm{ml} / \mathrm{L})$ & 0 & 2 & 5 & 8 & 10,05 \\
\hline
\end{tabular}




\section{Isolasi dan Identifikasi Bakteri}

Bakteri dari reaktor diisolasi dengan menggunakan media Stainer (Fujitani et al., 2015) yang dimodifikasi dengan penambahan 3,7 g/L sukrosa. Kemudian, isolat bakteri yang diperoleh diobservasi morfologi koloni, morfologi selnya dan diuji secara biokimia menggunakan VITEK GN+ (bioMerieux).

\section{Analisis Statistik}

Laju penurunan amonia, akumulasi nitrit dan nitrat dianalisa menggunakan aplikasi Microsoft Excel dan analisis model regresi Response Surface Methology (RSM) dengan rancangan Central Composite Design (CCD) menggunakan aplikasi Design Expert version 7.0.0 (Stat-Ease Inc., Minneapolis, MN, USA, 2005). Koefisien determinasi $\mathrm{R}^{2}$ menentukan kualitas persamaan regresi. Signifikansi diuji menggunakan uji-F serta uji kelayakan untuk memastikan asumsi ANOVA terpenuhi.

\section{HASIL DAN PEMBAHASAN}

Pengaruh sedimen kolam lele, sukrosa dan biofertilizer pada laju penurunan amonia, lajua kumulasi nitrit, dan laju akumulasi nitrat diamati. Hasilnya dapat dilihat pada Tabel 2.
Hasil analisis varian laju penurunan amonia, akumulasi nitrit, dan akumulasi nitrat selama kurun waktu \pm 21 hari disajikan dalam Tabel 3. $X_{1}, X_{2}$, dan $X_{3}$ masing-masing merupakan konsentrasi sedimen, sukrosa, dan biofertilizer. Sukrosa $\left(\mathrm{X}_{2}\right)$ terbukti secara signifikan mempengaruhi laju penurunan amonia $(\mathrm{p}<0,05)$. Selain itu, faktor kuadratik sedimen $\left(\mathrm{X}_{1}^{2}\right)$ dan interaksi antara sukrosa dan biofertilizer $\left(\mathrm{X}_{2} \mathrm{X}_{3}\right)$ juga menunjukkan pengaruh terhadap proses penurunan amonia $(\mathrm{p}<0,05)$. Hubungan antara dua variabel yang saling berinteraksi divisualisasikan dalam plot contour dan grafik tiga dimensi (Gambar 1).

Pada laju akumulasi nitrit, bakteri sedimen dan sukrosa $\left(\mathrm{X}_{1}\right.$ dan $\left.\mathrm{X}_{2}\right)$ menunjukkan pengaruh yang signifikan $(p<0,05)$, namun tidak ditemukan variabel yang signifikan pada kuadrat faktor. Selain itu, interaksi antara bakteri sedimen dan sukrosa $\left(\mathrm{X}_{1} \mathrm{X}_{2}\right)$ menunjukkan pengaruh terhadap laju akumulasi nitrit $(\mathrm{p}<0,05)$. Sementara itu, hanya sukrosa $\left(\mathrm{X}_{2}\right)$ yang terbukti secara signifikan mempengaruhi laju akumulasi nitrat $(\mathrm{p}<0,05)$. Hasil ini sesuai dengan penelitian lain yakni $p<0,05$ sehingga model lebih disukai dalam merepresentasikan hasil Mousavi dan Ibrahim, 2015)

Persamaan model regresi yang dihasilkan dari ANOVA dapat dilihat pada Tabel 4. Persamaan tersebut memperhitungkan bentuk linear, kuadratik, dan efek interaksi antar faktor-faktor yang diteliti.

Tabel 2. Pengaruh sedimen kolam lele, sukrosa dan biofertilizer terhadap laju penurunan amonia $\left(\mathrm{NH}_{3}-\mathrm{N}\right)$, laju akumulasi nitrit dan nitrat $\left(\mathrm{NO}_{3}-\mathrm{N}\right)$ menggunakan Central Composite Design (CCD)

\begin{tabular}{cccccccc}
\hline No & Std & $\begin{array}{c}\text { Sedimen } \\
(\mathbf{g} / \mathbf{L})\end{array}$ & $\begin{array}{c}\text { Glukosa } \\
(\mathbf{g} / \mathbf{L})\end{array}$ & $\begin{array}{c}\text { Biofertilizer } \\
(\mathbf{m L} / \mathbf{L})\end{array}$ & $\begin{array}{c}\text { Laju } \\
\mathbf{N H}_{3} \mathbf{-}\end{array}$ & $\begin{array}{c}\text { Laju } \\
\mathbf{N O}_{2}-\mathbf{N}\end{array}$ & $\begin{array}{c}\mathbf{L a j u} \\
\mathbf{N O}_{3}-\mathbf{N}\end{array}$ \\
\hline 1 & F1 & 20 & 0,7 & 2 & $-2,29$ & $-0,07$ & 1,38 \\
2 & F2 & 80 & 0,7 & 2 & $-1,05$ & $-0,22$ & 1,30 \\
3 & F3 & 20 & 6,7 & 2 & $-1,77$ & 0,81 & $-0,07$ \\
4 & F4 & 80 & 6,7 & 2 & $-2,24$ & $-0,09$ & 0,62 \\
5 & F5 & 20 & 0,7 & 8 & $-0,91$ & $-0,16$ & 0,99 \\
6 & F6 & 80 & 0,7 & 8 & $-1,45$ & $-0,04$ & 2,29 \\
7 & F7 & 20 & 6,7 & 8 & $-3,53$ & 1,02 & 0,18 \\
8 & F8 & 80 & 6,7 & 8 & $-3,00$ & 0,10 & $-0,05$ \\
9 & A1 & 0 & 3,7 & 5 & $-2,05$ & $-0,02$ & 0,74 \\
10 & A2 & 100 & 3,7 & 5 & $-1,26$ & $-0,07$ & 0,53 \\
11 & A3 & 50 & 0 & 5 & $-1,56$ & $-0,17$ & 1,74 \\
12 & A4 & 50 & 8,75 & 5 & $-2,75$ & 0,44 & 0,41 \\
13 & A5 & 50 & 3,7 & 0 & $-1,80$ & 0,10 & 0,58 \\
14 & A6 & 50 & 3,7 & 10 & $-2,62$ & 0,09 & 1,07 \\
15 & C1 & 50 & 3,7 & 5 & $-3,22$ & 0,08 & 0,24 \\
16 & C2 & 50 & 3,7 & 5 & $-2,15$ & 0,12 & 0,85 \\
17 & C3 & 50 & 3,7 & 5 & $-2,47$ & 0,22 & 0,78 \\
18 & C4 & 50 & 3,7 & 5 & $-3,07$ & 0,09 & 0,33 \\
19 & C5 & 50 & 3,7 & 5 & $-2,40$ & 0,14 & 0,67 \\
20 & C6 & 50 & 3,7 & 5 & $-3,29$ & $-0,10$ & 0,76 \\
\hline
\end{tabular}


Tabel 3. ANOVA untuk laju penurunan amonia

\begin{tabular}{|c|c|c|c|c|c|c|}
\hline \multicolumn{7}{|c|}{ ANOVA for Response Surface Quadratic Model } \\
\hline Source & $\begin{array}{r}\text { Sum of } \\
\text { Squares }\end{array}$ & df & $\begin{array}{r}\text { Mean } \\
\text { Square }\end{array}$ & F Value & $\begin{array}{r}\text { nilai p Prob } \\
>\text { F }\end{array}$ & \\
\hline \multicolumn{7}{|c|}{ Laju Penurunan Amonia $\left(\mathrm{NH}_{3}-\mathrm{N}\right)$} \\
\hline Model & 8,72 & 9 & 0,97 & 3,97 & 0,0213 & significant \\
\hline $\mathrm{X}_{2}$ & 3,43 & 1 & 3,43 & 14,07 & 0,0038 & significant \\
\hline $\mathrm{X}_{2} \mathrm{X}_{3}$ & 1,53 & 1 & 1,53 & 6,28 & 0,0311 & significant \\
\hline $\mathrm{X}_{1}^{2}$ & 2,05 & 1 & 2,05 & 8,38 & 0,0160 & significant \\
\hline Lack of fit & 1,26 & 5 & 0,25 & 1,07 & 0,4715 & not significant \\
\hline \multicolumn{7}{|c|}{$\mathrm{R}^{2}=0,7813$, Adequate Precision $=5,842$} \\
\hline \multicolumn{7}{|c|}{ Laju Akumulasi nitrit $\left(\mathrm{NH}_{2}-\mathrm{N}\right)$} \\
\hline Model & 1,57 & 9 & 0,17 & 5,48 & 0,0069 & significant \\
\hline $\mathrm{X}_{1}$ & 0,27 & 1 & 0,27 & 8,46 & 0,0156 & significant \\
\hline $\mathrm{X}_{2}$ & 0,82 & 1 & 0,82 & 25,81 & 0,0005 & significant \\
\hline $\mathrm{X}_{1} \mathrm{X}_{2}$ & 0,40 & 1 & 0,40 & 12,68 & 0,0052 & significant \\
\hline Lack of fit & 0,26 & 5 & 0,05 & 4,42 & 0,0642 & not significant \\
\hline \multicolumn{7}{|c|}{$\mathrm{R}^{2}=0,8315$, Adequate Precision $=8,052$} \\
\hline \multicolumn{7}{|c|}{ Laju Akumulasi nitrat (NH3-N) } \\
\hline Model & 5,04 & 9 & 0,56 & 3,74 & 0,0259 & significant \\
\hline $\mathrm{X}_{2}$ & 4,18 & 1 & 4,18 & 27,89 & 0,0004 & significant \\
\hline Lack of fit & 1,18 & 5 & 0,24 & 3,76 & 0,0863 & not significant \\
\hline
\end{tabular}

Catatan: $\mathrm{R}^{2}$ : determinasi, $\mathrm{X}_{1}$ : bakteri sedimen, $\mathrm{X}_{2}$ : sukrosa, $\mathrm{X}_{3}$ : biofertilizer

Tabel 4. Persamaan regresi pada penurunan amonia, akumulasi nitrit, dan akumulasi nitrat

\begin{tabular}{ll}
\hline \multicolumn{1}{c}{ Parameter } & \multicolumn{1}{c}{ Persamaan Regresi } \\
\hline Laju Penurunan & $y=-2,76+0,15 \mathrm{X}_{1}-0,50 \mathrm{X}_{2}-0,21 \mathrm{X}_{3}-0,081 \mathrm{X}_{1} \mathrm{X}_{2}-0,097 \mathrm{X}_{1} \mathrm{X}_{3}-$ \\
Amonia $\left(\mathrm{NH}_{3}-\mathrm{N}\right)$ & $0,44 \mathrm{X}_{2} \mathrm{X}_{3}+0,38 \mathrm{X}_{1}^{2}+0,20 \mathrm{X}_{2}^{2}+0,18 \mathrm{X}_{3}^{2}$ \\
\hline Laju Akumulasi Nitrit & $y=+0,087-0,14 \mathrm{X}_{1}+0,25 \mathrm{X}_{2}+0,035 \mathrm{X}_{3}-0,22 \mathrm{X}_{1} \mathrm{X}_{2}+0,029 \mathrm{X}_{1} \mathrm{X}_{3}$ \\
$\left(\mathrm{NO}_{2}-\mathrm{N}\right)$ & $+0,038 \mathrm{X}_{2} \mathrm{X}_{3}-0,024 \mathrm{X}_{1}^{2}+0,038 \mathrm{X}_{2}^{2} \quad+0,025 \mathrm{X}_{3}^{2}$ \\
\hline Laju Akumulasi Nitrat & $y=+0,61+0,097 \mathrm{X}_{1}-0,55 \mathrm{X}_{2}+0,075 \mathrm{X}_{3}-0,094 \mathrm{X}_{1} \mathrm{X}_{2}+0,056 \mathrm{X}_{1} \mathrm{X}_{3}-$ \\
$\left(\mathrm{NO}_{3}-\mathrm{N}\right)$ & $0,13 \mathrm{X}_{2} \mathrm{X}_{3}+0,004 \mathrm{X}_{1}^{2}+0,16 \mathrm{X}_{2}^{2}+0,071 \mathrm{X}_{3}^{2}$ \\
\hline
\end{tabular}

Hasil ANOVA pada laju penurunan amonia, laju akumulasi nitrat dan nitrit secara signifikan menunjukkan model regresi yang sesuai $(p<0,05)$. Sementara itu, ditinjau uji ketidaksesuaian (lack of fit) menunjukkan $(p>0,1)$ sehingga tidak ada lack of fit pada model, artinya model yang diusulkan telah sesuai dengan data eksperimen (Shabbiri et al., 2012). Model kuadratik menunjukkan bahwa $\mathrm{R}^{2}$ sebesar $0.7813\left(\mathrm{NH}_{3}-\mathrm{N}\right)$, $0,8315\left(\mathrm{NO}_{2}-\mathrm{N}\right)$, dan $0,7652\left(\mathrm{NO}_{3}-\mathrm{N}\right)$ yang berarti sekitar 78,13\%; 83,15\%; dan 76,52\% variasi dari respon (laju penurunan amonia, laju akumulasi nitrit dan nitrat) dipengaruhi oleh variabel $\mathrm{X}$, sedangkan sisanya dipengaruhi oleh variabel yang belum diketahui. Selain itu, nilai presisi (Adequate Precision) yang diperoleh pada penelitian ini lebih dari 4 , yang berarti sinyal telah memadai, yakni nilai yang diprediksi pada model terhadap kesalahan prediksi rata-rata masih dapat ditoleransi sehingga secara signifikan menyatakan kesesuaian model (Thakkar dan Saraf, 2014).

Untuk memastikan bahwa asumsi ANOVA terpenuhi, dilakukan uji residual untuk menentukan kelayakan model regresi. Hasilnya menunjukkan bahwa titik residu terletak disekitar garis linier yang berarti model terdistribusi normal. Selain itu, nilai residual versus nilai prediksi memperlihatkan titik residu yang menyebar secara acak dan tidak membentuk magapon (Chun et al., 2015; El-Gendy et al., 2013). Representasi hasil dapat dilihat pada Gambar 2.

Berdasarkan persamaan yang diperoleh pada laju penurunan amonia, laju akumulasi nitrit dan nitrat maka nilai prediksi pada kondisi optimal akan diperoleh jika jumlah sedimen ikan lele adalah $74 \mathrm{~g} / \mathrm{L}$, sukrosa 6,6 g/L sukrosa, dan biofertilizer 7,5 $\mathrm{mL} / \mathrm{L}$. Untuk memverifikasi model, penelitian dilanjutkan dengan menggunakan jumlah sedimen ikan lele, sukrosa dan biofertilizer yang disarankan. Hasilnya dapat dilihat padaTabel 5.

Nilai verifikasi pada laju penurunan amonia menurun $25 \%$ dibandingkan nilai prediksi, namun meningkat $7 \%$ dibandingkan dengan nilai optimasi. Sementara itu, nilai verifikasi laju akumulasi nitrit menurun $191 \%$ dibandingkan nilai prediksi dan menurun $224 \%$ dibandingkan nilai optimasi. Selanjutnya, nilai verifikasi pada laju akumulasi nitrat menurun $94 \%$ dibandingkan nilai prediksi dan menurun $97,9 \%$ dibandingkan nilai optimasi. 


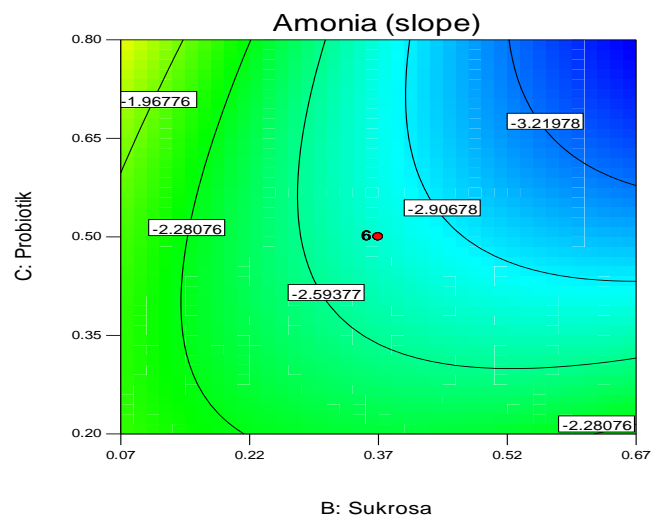

(a)

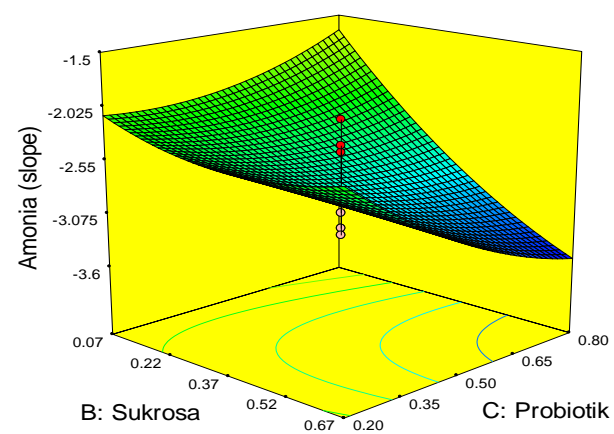

(b)

Gambar 1. Plot Contour (A) dan Grafik 3D (B) untuk laju penurunan amonia. laju penurunan amonia semakin tinggi ketika konsentrasi Biofertilizer (probiotik) dan sukrosa semakin tinggi

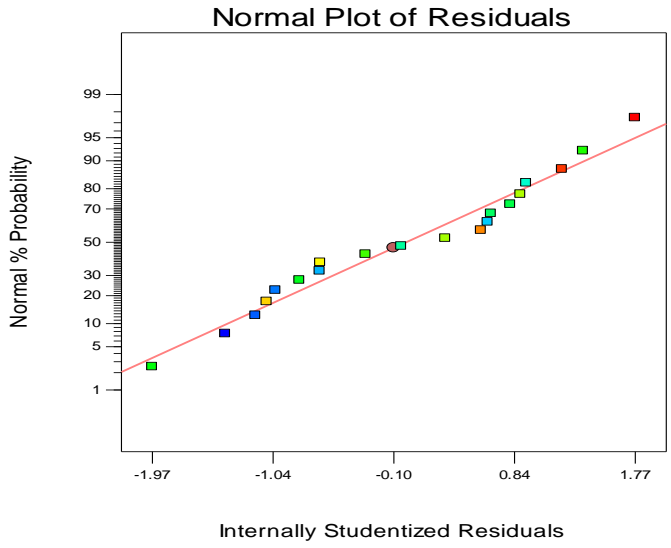

(a)

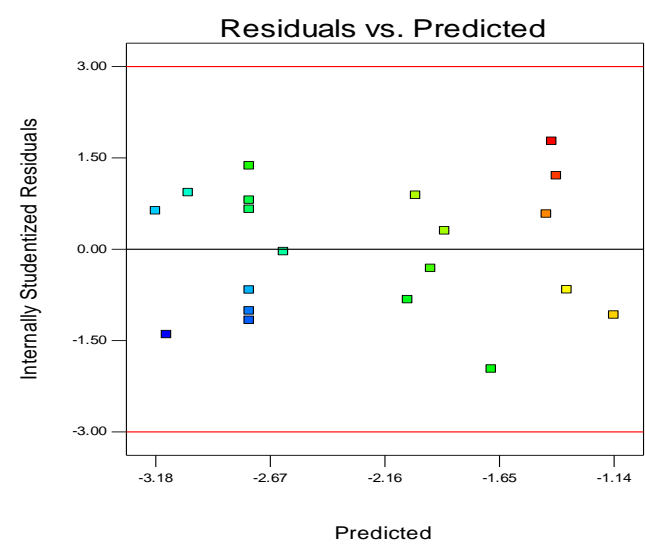

(b)

Gambar 2. Uji residual model regresi pada laju oksidasi amonia. model regresi dianggap layak jika A) Plot residual normalitas berada disepanjang garis linear, dan B) plot residual menyebar secara acak

Tabel 5. Verifikasi eksperimen pengaruh sedimen ikan lele, sukrosa dan biofertilizer terhadap laju penurunan ammonia, akumulasi nitrit dan nitrat

\begin{tabular}{|c|c|c|c|}
\hline & $\begin{array}{c}\text { Laju penurunan } \\
\text { Amonia }\left(\mathrm{NH}_{3}-\mathrm{N}\right) \mathrm{ppm}\end{array}$ & $\begin{array}{c}\text { Laju akumulasi nitrit } \\
\left(\mathrm{NO}_{2}-\mathrm{N}\right) \mathrm{ppm}\end{array}$ & $\begin{array}{c}\text { Laju akumulasi } \\
\text { nitrat }\left(\mathrm{NO}_{3}-\mathrm{N}\right) \text { ppm }\end{array}$ \\
\hline Nilai Prediksi & $-3,227$ & 0,155 & 0,276 \\
\hline Nilai Optimasi Rata-rata & $-2,244$ & 0,114 & 0,752 \\
\hline Nilai Verifikasi Rata-rata & $-2,408$ & $-0,142$ & 0,016 \\
\hline
\end{tabular}

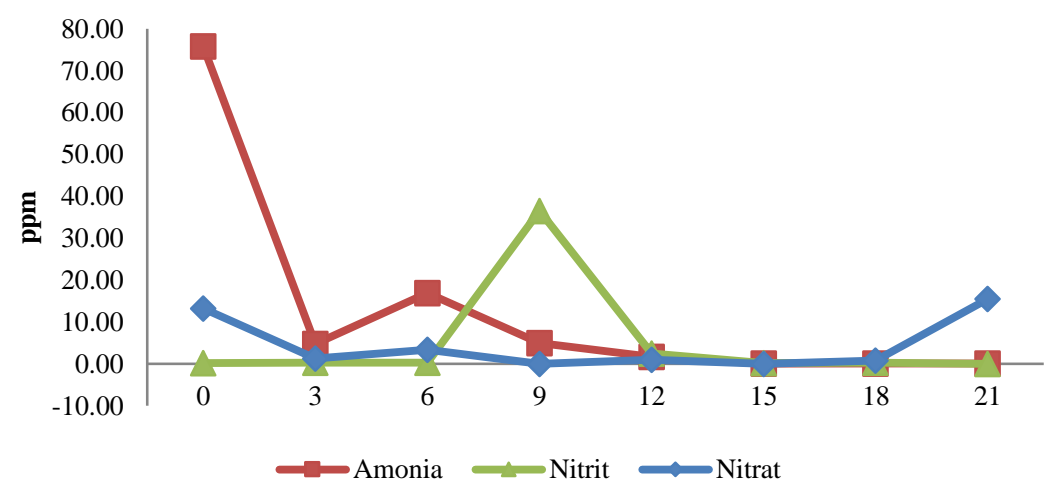

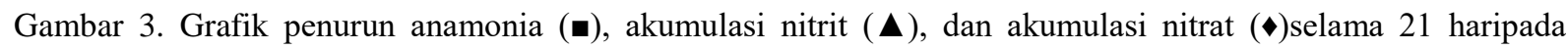
proses nitrifikasi 
Hasil ini mengindikasikan bahwa pada reaktor terjadi proses nitrifikasi heterotrof dan denitrifikasi aerobic. Penurunan amonia mencapai $99,85 \%$ dari konsentrasi awal amonia $\left(\mathrm{NH}_{3}-\mathrm{N}\right) 75,77$ ppm menjadi 0,11 ppm (Gambar 3). Kadar amonia yang rendah ini terus berlangsung hingga 21 hari pengamatan. Meskipun demikian, penurunan amonia yang tajam ini tidak diikuti oleh peningkatan nitrit dan nitrat yang nyata kecuali nitrit pada hari ke 9 dan nitrat pada hari ke 21 .

Proses nitrifikasi secara umum dilakukan oleh bakteri pengoksidasi amonia atau disebut juga sebagai bakteri nitrifikasi autotrof seperti Nitrosomonas yang kemudian diikuti bakteri pengoksidasi nitrit seperti Nitrobacter (Ebeling et al., 2006). Pada penelitian Hommes et al. (2003), Nitrosomonas europaea yang merupakan bakteri nitrifikasi autotrof yang tidak dapat tumbuh pada media glukosa, namun dapat mentolelir media fruktosa tunggal. Kehadiran sukrosa pada reaktor mendukung pertumbuhan bakteri nitrifikasi heterotrof. Dalam penelitian ini, sukrosa berpengaruh signifikan terhadap penurunan amonia $\left(\mathrm{NH}_{3}-\mathrm{N}\right)$.

Penurunan amonia akan menghasilkan nitrit dan selanjutnya nitrit akan teroksidasi kembali menjadi nitrat. Proses ini berlangsung pada suasana aerobik oleh bakteri nitrifikasi heterotrof seperti Agrobacterium sp. (Chen dan Ni, 2012), Bacillus subtilis (Yang et al., 2011), Chryseobacterium haifense (Kundu et al., 2014), Klebsiella pneumonia (Padhi et al., 2013), dan Achromobacter xylosoxidans (Kundu et al., 2012). Berdasarkan analisis statistik ANOVA, sukrosa dan biofertilizer menunjukkan pengaruh yang signifikan terhadap laju akumulasi nitrit.

Dalam penelitian ini, laju akumulasi nitrat dipengaruhi oleh sukrosa secara signifikan walaupun kehadiran sukrosa menyebabkan fluktuasi pada laju akumulasi nitrat yang ditandai dengan terjadinya penurunan konsentrasi nitrat. Hal ini mungkin disebabkan oleh kehadiran bakteri denitrifikasi aerobik yang berasal dari genera heterotrof, seperti Pseudomonas, Achromobacter, Acinetobacter (Zhu et al., 2012) dan Bacillus subtilis (Yang et al., 2011). Bakteri denitrifikasi heterotrof menggunakan enzim nitrate periplasmic reductase untuk melakukan aktivitas denitrifikasi aerobik (Zhu et al., 2012). Beberapa bakteri denitrifikasi mampu memanfaatkan amonia sebagai sumber energi untuk bertahan hidup. Bakteri tersebut disebut sebagai bakteri nitrifikasidenitrifikasi simultan yang dapat melakukan proses nitrifikasi heterotrof dan denitrifikasi aerobik (Shoda dan Ishikawa, 2014). Beberapa genus bakteri tersebut diantaranya Thiosphaera patotropha, $B$. subtilis, Agrobacterium sp., $\quad$ Rhodococcus sp., K. pneumonia dan Marinobacter sp. yang memilki jalur nitrifikasi dan denitrifikasi lengkap $\left(\mathrm{NH}_{4}{ }^{+} \rightarrow\right.$ $\mathrm{NH}_{2} \mathrm{OH} \rightarrow \mathrm{NO}_{2}{ }^{-} \rightarrow \mathrm{NO}_{3}{ }^{-} \rightarrow \mathrm{N}_{2} \mathrm{O} \rightarrow \mathrm{N}_{2}$ )serta bakteri
Alcaligenes faecalis dan Alcaligenes calcoaceticus yang bisa melakukan nitrifikasi dan denitrifikasi simultan tanpa melalui jalur nitrit dan nitrat $\left(\mathrm{NH}_{4}{ }^{+} \rightarrow \mathrm{NH}_{2} \mathrm{OH} \rightarrow \mathrm{N}_{2} \mathrm{O} \rightarrow \mathrm{N}_{2}\right.$ ) (Kundu et al. 2014).

Secara teoritis, bakteri nitrifikasidenitrifikasi simultan mengalami koeksistensi ketika oksigen terlarut mencapai 0,3 - 0,8 ppm (Peng dan Qi, 2007). Bakteri B. licheniformis dapat mengoksidasi amonia 56-67\% sekitar 40 ppm dengan kehadiran oksigen terlarut sekitar 5 ppm (Khanichaidecha et al., 2018). Acinetobacter dapat mentolerir oksigen terlarut 3 - $10 \mathrm{mg} / \mathrm{L}$ (Zhu et al., 2012) dan Bacillus subtilis pada rentang 3,93 - 7,65 ppm (Yang et al., 2011). Pada penelitian ini, konsentrasi oksigen terlarut berada pada rentang 5,3 - 7,8 ppm. Fluktuatifitas oksigen terlarut disebabkan oleh penggunaan oksigen dalam proses nitrifikasi serta proses respirasi aerobik melalui jalur karbon berupa sukrosa. Sementara itu, suhu berada pada rentang $25,8-27,7^{\circ} \mathrm{C}$. Fluktuatifitas suhu kemungkinan besar dipengaruhi oleh suhu lingkungan.

Pada penelitian ini, $\mathrm{pH}$ yang teramati cenderung fluktuatif dengan rentang $\mathrm{pH}$ 2,5-7,6. Kondisi asam pada reaktor diasumsikan oleh kehadiran bakteri Lactobacillus plantarum yang berasal dari biofertilizer. Penelitian Smetanková et al. (2012), menunjukkan bahwa Lactobacillus plantarum dapat menghasilkan asam laktat dengan rentang 9,83-11,48 $\mathrm{g} / \mathrm{L}$ dan asam asetat sekitar $1,03-1,65 \mathrm{~g} / \mathrm{L}$ dalam kondisi aerobik lebih tinggi dibandingkan pada kondisi anaerobik. Kehadiran Lactobacillus tidak mendominasi pada waktu tertentu, produksi asam dari Lactobacillus tidak mendominasi sehingga $\mathrm{pH}$ reaktor kembali menjadi basa. Lactobacillus juga ditemukan dapat mendegradasi nitrit dan mengakumulasi $\mathrm{N}_{2} \mathrm{O}$ melalui jalur respirasi nitrat (Liu et al., 2014).

\section{Isolasi, Karakterisasi dan Identifikasi Bakteri Nitrifikasi}

Berdasarkan pengamatan morfologi koloni, morfologi sel, dan uji biokimia menggunakan VITEK GN+ (biomeriex) diperoleh empat isolat beda yaitu, isolat L1, L2, L3, L4. Namun, hanya isolat L2, L3 danL4 yang disertakan dalam uji biokimia menggunakanVITEK GN+ (bioMerieux). Berdasarkan pengamatan yang dilakukan dibuktikan bahwa isolat L1, L2, L3, L4 murni berasal dari sedimen kolam lele. Hal ini dikarenakan tidak tersisolasinya bakteri Biofertilizer, seperti Nitrosomonas europaea sebagai bakteri pengoksidasi amonia autotrof (Caranto dan Lancaster, 2017) maupun Bacillus subtilis dan Bacillus apiarius. Menurut Yao et al. (2014), kelompok bakteri Bacillus mampu melakukan proses nitrifikasi-denitrifikasi. 
Tabel 6. Isolasi, karakterisasi dan identifikasi bakteri nitrifikasi

\begin{tabular}{|c|c|c|c|c|}
\hline Bakteri & Isolat L1 & Isolat L2 & Isolat L3 & Isolat L4 \\
\hline \multicolumn{5}{|l|}{ Morfologi Koloni } \\
\hline Warna & $\begin{array}{l}\text { Merah } \\
\text { muda }\end{array}$ & Kuning & Putih & Putih kecoklatan \\
\hline Bentuk & Bundar & Bundar & Bundar & bundar \\
\hline Tepian & Licin & Licin & Licin & Licin \\
\hline Elevasi & Cembung & Cembung & Datar & Datar \\
\hline \multicolumn{5}{|l|}{ Morfologi Sel } \\
\hline Bentuk sel & Basil & Basil & Basil & Kokus \\
\hline Warna Sel & Merah & Merah & Merah & Merah \\
\hline \multicolumn{5}{|l|}{ Biokimia } \\
\hline Persentase VITEK & & $99 \%$ & $98 \%$ & $93 \%$ \\
\hline GN+ (bioMerieux) & - & $\begin{array}{c}\text { (Sphingobacterium } \\
\text { thalpophilum) }\end{array}$ & $\begin{array}{c}\text { (Cupriavidus } \\
\text { pauculus) }\end{array}$ & $\begin{array}{c}\text { (Burkholderia } \\
\text { cepacia) }\end{array}$ \\
\hline
\end{tabular}

Pada Tabel 6, isolat $\mathrm{L} 2$ diindikasikan
sebagai bakteri jenis $\begin{aligned} & \text { Sphingobacterium } \\ & \text { thalpophilum berdasarkan uji biokimia dengan }\end{aligned}$
probabilitas mencapai 99\%. Genus Sphingobacteria
merupakan genus bakteri denitrifikasi yang masuk
dalam proses Coupled Nitrification-Denitrification
(CND), yaitu jalur nitrifikasi $\mathrm{NH}_{4}^{+} \rightarrow \mathrm{N}_{2} \mathrm{O} \rightarrow \mathrm{N}_{2}$
(Codispoti dan Christensen, 1985; Zhu et al., 2018).
Pada uji biokimia VITEK $\mathrm{GN}+$ (bioMerieux),
Sphingobacterium thalpophilum dapat menggunakan
Saccharose/Sucrose (SAC) dan memproduksi enzim
Alpha-Glucosidase (AGLU), Beta-Glucuronidase (BGUR), Ala-Phe-Pro-Arylamidase (APPA), dan Tyrosine Arylamidase (TyrA).

Isolat L3 diindikasikan sebagai bakteri jenis Cupriavidus pauculus berdasarkan uji biokimia dengan probabilitas mencapai 98\%. Cupriavidus pauculus termasuk dalam golongan bakteri nitrifikasi-denitrifikasi heterotrof, namun sementara adalah bakteri nitrifikasi heterotrof dikarenakan tidak menghasilkan $\mathrm{N}_{2}$ dan $\mathrm{N}_{2} \mathrm{O}$. Penelitian Ramirez et al. (2014), memperlihatkan bahwa Cupriavidus pauculus mengpenurunan PO (Piruvate oxime) tanpa menghasilkan $\mathrm{N}_{2}$ dan $\mathrm{N}_{2} \mathrm{O}$, namun menjadi $\mathrm{NO}_{2}-$ yang mungkin melalui jalur organik, yaitu melalui perantara karbon dan bukan melalui $\mathrm{NH}_{2} \mathrm{OH}$. Cupriavidus pauculus dapat memprodukasi $L$ Pyrrolydonyl-Arylamidase (PyrA), L-Proline Arylamidase (ProA), Gamma-Glutamyl-Tranferase (GGT) dan dapat menggunakan Citrate/Sodium (CIT), Malonate (MNT), L-Lactate Alkalinisation (ILATk), Succinate Alkalinisation (SUCT), L-malate assimilation, dan 5-5-dithiobis-(2-nitrobenzoic acid) atau (ELLM).

Isolat L4 memiliki probabilitas mencapai 93\% dengan jenis bakteri Burkholderia cepacia. Namun, terdapat $7 \%$ kemungkinan bahwa jenis bakteri bukan Burkholderia cepacia. Burkholderia cepacia memiliki sel berbentuk basil (Omar et al., 2015), sementara isolat L4 memiliki sel berbentuk kokus.

\section{KESIMPULAN DAN SARAN}

\section{Kesimpulan}

Model regresi Central Composite Design (CCD) dengan analisis statistik Response Surface Method (RSM) dalam simulasi proses nitrifikasi menggunakan amonia $\left(\mathrm{NH}_{3}-\mathrm{N}\right) 77,65$ ppm selama \pm 21 hari dianggap layak berdasarkan uji determinasi $\left(\mathrm{R}^{2}\right)$, presisi, dan uji kelayakan. Persamaan model regresi laju penurunan amonia:

$$
\begin{aligned}
y= & -2,76+0,15 X_{1}-0,50 X_{2}-0,21 X_{3}-0,081 X_{1} X_{2}- \\
& 0,097 X_{1} X_{3}-0,44 X_{2} X_{3}+0,38 X_{1}^{2}+0,20 X_{2}^{2}+ \\
& 0,18 X_{3}^{2}
\end{aligned}
$$

Berdasarkan persamaan model regresi diperoleh nilai optimal kolam lele $74 \mathrm{~g} / \mathrm{L}$, sukrosa $6,6 \mathrm{~g} / \mathrm{L}$, dan biofertilizer 7,4 g/L dengan penurunan ammonia mencapai $99,85 \%$ ppm pada kurun waktu 21 hari.

Hasil isolasi, karakterisasi dan identifikasi bakteri berdasarkan uji morfologi koloni, morfologi sel, dan uji biokimia diperoleh indikasi bahwa bakteri yang berhasil diisolasi termasuk kedalam jenis Sphingobacterium thalpophilum (probablilitas =99\%) dan Cupriavidus pauculus (probabilitas = 98\%). Kedua jenis bakteri ini terbukti mampu melakukan proses nitrifikasi dan denitrifikasi.

\section{Saran}

1. Bakteri yang telah diisolasi perlu diuji kembali kinerjanya dalam proses nitrifikasi menggantikan sedimen kolam lele sehingga model regresi akan lebih baik dan diperoleh pemodelan yang lebih paripurna.

2. Perlu dilakukan penelitian aplikasi proses dilapangan untuk menangani pencemaran amonia.

\section{UCAPAN TERIMA KASIH}

Ucapan terimakasih kami sampaikan kepada Pusat Teknologi Pengolahan Air Limbah BPPT yang telah membiayai penelitian ini melalui INSINAS 2017 dan 2018 Kementrian Ristek Diksti. 


\section{DAFTAR PUSTAKA}

Bezerra BA, Santelli RE, Oliveira EP, Villar LS, Escaleira LA. 2008. Response surface methodology (RSM) as a tool for optimization in analytical chemistry. Jurnal Talanta. 76:965-977.

Caranto JD dan Lancaster KM. 2017. Nitric oxide is an obligate bacterial nitrification intermediate produced by hydroxylamine oxidoreductase. J PNAS: 1-6.

Chen $\mathrm{Q}$ dan Ni J. 2012. Ammonium removal by Agrobacterium sp. LAD9 capable of heterotrophic nitrification-aerobic denitrification. Journal of Bioscience and Bioengineering. 113(5): 619-623.

Chun CW, Jamaludin NFM dan Zainol N. 2015. Optimization of biogas production from poultry manure wastewater in $250 \mathrm{ml}$ flasks. Jurnal Teknologi.75(1):275-285.

Codispoti LA dan Christensen JP. 1985. Nitrification, denitrification and nitrous oxide cycling in the eastern tropical South Pacific ocean. Marine Chemistry, 16(4): 277-300.

Ebeling JM, Timmons MB dan Bisogni JJ. 2006. Engineering analysis of the stoichiometry of photoautotrophic, autotrophic, and heterotrophic removal of ammonianitrogen in aquaculture systems. Aquaculture. 257(1-4): 346-358.

Effendi H, Utomo BA, Darmawangsa GM, Karokaro RE. 2015. Fitoremediasi limbah budidaya ikan lele (Clarias Sp.) dengan kangkung (Ipomoea Aquatica) dan pakcoy (Brassica Rapa Chinensis) dalam sistem resirkulasi. Ecolab. 9(2): 47-104.

El-GendyNS, Madian HR, dan Amr SSA. 2013. Design and optimization of a process for sugarcane molasses fermentation by Saccharomyces cerevisiae Using Response Surface Methodology. International Journal Microbiology. 2013:1-9.

Fujitani H, Kumagai A, Ushiki N, Momiuchi K, Tsuneda S. 2015. Selective isolation of ammonia-oxidizing bacteria from autotrophic nitrifying granules by applying cell-sorting and sub-culturing of microcolonies. Frontiers in Microbiology. 6:1159.

Gunadi B dan Hapsaridewi R. 2008. Pengendalian Limbah Amonia Budidaya Ikan Lele dengan Sistem Heterotrofik Menuju Sistem Akuakultur Nir-Limbah. Jurnal Ris. Akuakultur. 3(3): 437-448.

Good AG dan Beatty PH. 2011. Fertilizing Nature: A Tragedy of Excess in the Commons. PLoS Biology. 9(8):1-9,
Harahap S. 2013. Pencemaran perairan akibat kadar amonia yang tinggi dari limbah cair industri tempe. Jurnal Akuatika. 4(2): 183-194.

Hastuti YP. 2011. Nitrifikasi dan denitrifikasi di kolam. Jurnal Akuakultur Indonesia, 10(1): 89-98.

Hommes NG, Sayavedra-Soto LA dan Arp DJ. 2003. Chemolithoorganotrophic Growth of Nitrosomonas europaea on Fructose. Journal Bacteriol. 185(23): 6809-6814.

Khanichaidecha W, NakarukA, Ratananikom K, Eamrat R, Kazama F. 2018. Heterotrophic nitrification and aerobic denitrification using pure-culture bacteria for wastewater treatment. Journal Water Reuse and Desalination, 2018064. doi 10.2166.

Kundu P, Pramanik A, Dasgupta A, Mukherjee S, Mukherjee J. 2014. Simultaneous heterotrophic nitrification and aerobic denitrification by Chryseobacterium sp. R31 Isolated from Abattoir Wastewater. BioMed Research International, 2014:12.

Kundu P, Pramanik A, Mitra S, Choudhury JD, MukherjeeJ, Mukherjee S. 2012. Heterotrophic nitrification by Achromobacter xylosoxidans S18 isolated from a small-scale slaughterhouse wastewater. Bioprocess and Biosystems Engineering.35(5): 721-728.

Liu D-M, Wang P, Zhang, X-y, Wu H, Li L. 2014. Characterization of Nitrite Degradation by Lactobacillus caseisubsp. rhamnosus LCR 6013. PLOS ONE 9(4): 93308. doi 10.1371 .

Mousavi SA dan Ibrahim S. 2015. Application of response surface methodology (RSM) for analyzing and modeling of nitrification process using sequencing batch reactors. Desalination and Water Treatment. 1-10.

Nainggolan TA, Khotimah S, dan Turnip M. 2015. Bakteri pendegradasi amonia limbah cair karet pontianak kalimantan barat. Protobiont. 4(2) : 69-76.

National Research Council. 2008. Acute Exposure Guideline Levels for Selected Airborne Chemicals.Washington DC: National Academy Press, P6.

Nuryanti dan Salimy DH. 2008. Metode permukaan respon dan aplikasinya pada optimasi eksperimen kimia. Risalah Lokakarya Komputasi dalam Sains dan Teknologi Nuklir. 373-391.

Ogbonna J dan Chinomso A. 2010. Determination of the concentration of ammonia that could have lethal effect on fish pond. Arpn Journal Engineering And Applied Sciences. 5(2): 1-4.

Omar N, Raouf HAE, Okasha H, Nabil N. 2015. Microbiological Assessment of 
Burkholderia cepacia complex (Bcc) isolated in Alexandria Main University Hospital. Alexandria Journal Medicine, 51(1):41-46

Padhi SK, Tripathy S, Sen, MahapatraAS, Mohanty S, Maiti NK. 2013. Characterisation of heterotrophic nitrifying and aerobic denitrifying Klebsiella pneumoniae CF-S9 strain for bioremediation of wastewater. International Biodeterioration and Biodegradation. 78: 67-73.

Peng Z dan Qi Z. 2007. Simultaneous nitrification and denitrification in activated sludge system under low oxygen concentration. Front Environ. Sci. En. 1: 49-52.

Peraturan Menteri Lingkungan Hidup Republik Indonesia. 2014. Baku Mutu Air Limbah. Indonesia, P1815.

Ramirez M, Obrzydowski J, Ayers M, Virparia S, Wang M, Stefan K, Castignetti D. 2014. Pyruvic oxime nitrification and copper and nickel resistance by a cupriavidus pauculus, an active heterotrophic nitrifierdenitrifier. The Scientific World Journal. 2014 (901702): 1-11.

Shabbiri K, Adnan A, Jamil S, Ahmad W, Noor B and Rafique H M 2012 Medium optimization of protease production by Brevibacterium linens DSM 20158, using statistical approach Brazilian. Journal Microbiology. 43(3).

Shoda M dan Ishikawa Y. 2014. Heterotrophic nitrification and aerobic denitrification of high-strength ammonium in anaerobically digested sludge by Alcaligenes faecalis strain No. 4. Journal Bioscience and Bioengineering, 117(6):737-741.

Smetanková J, Hladíková Z, Valach F, Zimanová M, Kohajdová Z, Greif G, Greifová M.2012.
Influence of aerobic and anaerobic conditions on the growth and metabolism of selected strains of Lactobacillus plantarum. Acta Chimica Slovaca. 5(2):204-210

Thakkar A dan Saraf M. 2014. Application of Statistically Based Experimental Designs to optimize cellulase production and identification of gene. Natural Products and Bioprospecting, 4(6):341-351.

Yang XP, Wang SM, Zhang DW, Zhou LX. 2011. Isolation and nitrogen removal characteristics of an aerobic heterotrophic nitrifying-denitrifying bacterium, Bacillus subtilis A1. Bioresource Technology, 102(2):854-862.

Yao Q dan Peng DC. 2017. Nitrite oxidizing bacteria (NOB) dominating in nitrifying community in full-scale biological nutrient removal wastewater treatment plants. AMB Express. 7:25.

Zhu L, Ding W, Feng LJ, Kong Y, Xu J, Xu XY. 2012.Isolation of aerobic denitrifiers and characterization for their potential application in the bioremediation of oligotrophic ecosystem. Bioresource Technology.108: 1-7.

Zhu W, Wang C, Hill J, He Y, Tao B, Mao Z, dan Wu W. 2018. A missing link in the estuarine nitrogen cycle?: Coupled nitrification-denitrification mediated by suspended particulate matter. Scientific Reports. 8(2282). doi 10.1038. 